\title{
Thermodynamic rigid cushion loading indenter: A buttock-shaped temperature and humidity measurement system for cushioning surfaces under anatomical compression conditions
}

\author{
Martin Ferguson-Pell, PhD; ${ }^{\mathbf{1}^{*}}$ Hideyuki Hirose, $\mathbf{P h D} ;^{\mathbf{2}}$ Graham Nicholson, $\mathbf{P h D} \mathbf{;}^{\mathbf{3}}$ Evan Call, $\mathrm{MS}^{\mathbf{4}}$ \\ ${ }^{1}$ Faculty of Rehabilitation Medicine, University of Alberta, Edmonton, Canada; ${ }^{2}$ Research Institute, National \\ Rehabilitation Center for Persons with Disabilities, Tokorozawa, Japan; ${ }^{3}$ ASPIRE Centre for Disability Sciences, \\ Institute of Orthopaedics, University College London, Stanmore, United Kingdom; ${ }^{4}$ Weber State University, Ogden, UT
}

\begin{abstract}
A method is described for measuring the heat and water vapor dissipation characteristics of wheelchair cushions and seating systems while under simulated loading conditions. Thermal interaction between the body and seating surfaces can result in elevated tissue temperature and moisture build-up, which may increase the risk of pressure ulcers associated with prolonged ischemia or due to macerative damage. Both the materials and geometry of commercial seating systems are thought to influence the body-support surface microclimate. A thermodynamic rigid cushion loading indenter (TRCLI) has been developed to simulate the thermal and loading conditions of the body on seating surfaces. Results are reported for 32 commercially available wheelchair cushions. The results differentiate the cushions into clusters of comparable properties that offer the potential for classification of support surfaces based on their heat and water vapor dissipation performance. This study has shown that deducing the heat and water vapor dissipation characteristics of a seating system from material physical properties is of limited value because of the influences of particular design features of combinations of materials. Testing of individual products with the use of the TRCLI can, however, reliably differentiate wheelchair cushions by their ability to dissipate heat and water vapor.
\end{abstract}

Key words: anatomical loading, heat and water vapor dissipation, humidity, pressure ulcer, rehabilitation, seating, temperature, test method, thermal properties, wheelchair cushion.

\section{INTRODUCTION}

Systematic research to address the prevention of pressure ulcers has been in progress for over 30 years. In this time, the reported prevalence of pressure ulcers in patientcare settings has not improved and may have even deteriorated [1-3]. Although much attention has been directed to the reduction of ischemia-initiated soft tissue injury through mechanical means, the influence of tissue temperature and the effect of moisture have been neglected. Kokate et al. have shown in an animal model that pressure ulcer incidence can be correlated with elevated tissue temperature [4]. Soft tissue fragility also increases in the presence of

\footnotetext{
Abbreviations: ANOVA $=$ analysis of variance, $\mathrm{CEP}=$ Centres for Evidence-Based Purchasing, CLI = cushion loading indenter, $\mathrm{CV}=$ coefficient of variation, $\mathrm{HWVD}=$ heat and water vapor dissipation, ISO = International Organization for Standardization, IT $=$ ischial tuberosity, $\mathrm{NHS}=$ National Health Service (UK), PU = pressure ulcer, RCLI = rigid cushion loading indenter, $\mathrm{RH}$ = relative humidity, TRCLI = thermodynamic rigid cushion loading indenter.

*Address all correspondence to Martin Ferguson-Pell, PhD; Faculty of Rehabilitation Medicine, University of Alberta, Edmonton, Canada, T6G 2G4; 780-492-5991; fax: 780-492-1626. Email: martin.ferguson-pell@ualberta.ca DOI:10.1682/JRRD.2008.10.0142
} 
moisture [5]. Support surfaces such as wheelchair cushions, other seating surfaces, and mattresses can have a major influence on the microclimate experienced by these tissues and are thought to be the result of a complex interaction between tissue physiology, environmental conditions, and the properties of the materials used in the construction of the seating system when loaded by the body and their overall geometry [6]. The requirements of users of seating systems also vary considerably depending on levels of exertion, environmental conditions, and physiological factors, including those that may be associated with pathology (e.g., reflex sweating or vulnerability to hyper- or hypothermia) [7].

While the relative impact of heat build-up on pressure ulcer formation has not been determined, significant evidence exists implicating heat as a major contributor in ulcer formation. The role of elevated tissue temperature on injury risk appears to be associated with the rate at which metabolic reactions occur, as stated in Arrhenius equation [8]. The opposite is certainly true, where surgical hypothermia reduces metabolic activity, extending tissue survival time under conditions of reduced blood flow or ischemia [9-10]. Heat trapping caused by lying on thermal insulating support surfaces or being seated on a cushion is thought to increase metabolic demand at a time when ischemia limits the exchange of tissue metabolites. Many products intended for pressure ulcer prevention claim to improve microclimate, yet reliable tools for measurement of body support surface conditions have not been developed.

Clinicians and users who want to make an informed selection of a support service would value information about its heat and water vapor dissipation characteristics. Although systems have been developed for measuring the heat and water vapor dissipation (HWVD) characteristics of flat support surfaces such as mattresses [11-12], an anatomically shaped analog or mannequin for this purpose has not been reported in the literature. The use of a buttockshaped system for cushions or a supine mannequin for mattresses provides the surface compression and associated local changes in heat and moisture permeation that are present in actual use by humans. Achieving an anatomical fit between the contoured HWVD-loading indenter and the seating surface is vital; otherwise, a large void can be created between a flat HWVD indenter and a contoured seat surface, yielding unrepresentative information. It is also likely that the HWVD characteristics of some materials are significantly altered when loaded, particularly those made from porous compressible materials or comprising columnar structures.
Cushion loading indenters (CLI) have been developed and used in a number of standardized test methods for assessing the characteristics of seat cushions [13-16]. The CLI reported in International Organization for Standardization (ISO) 16840-2 [16] is a simple-to-fabricate representation of the human buttock, comprising simple conical components, that can be fabricated in both solid and hollow forms. The dimensions of the mold-forms needed to construct the buttock-shaped indenters are given in Appendix A of ISO 16840-2 [16] and come in two sizes. The ability of this specific shape to generate loading representative of that seen in human volunteers has been demonstrated by Staarink [17].

A number of techniques have been reported for measuring heat and water vapor transfer through clothing [18-19]; however, they are not designed to apply mechanical loading to the tested material. Sweating hotplates have also been used in a nominally unloaded state to measure HWVD in flat surfaces such as mattresses and overlays [11,18-26].

Studies in the clothing industry have been ongoing for at least 50 years, resulting in the development of a number of test methods that measure classical thermodynamic properties such as heat and/or moisture dissipation [2728]. These methods provide information in heat and mass transfer units for the calculation of thermal resistances of individual clothing layers and are normally based on steady-state conditions. Seating systems, on the other hand, have complex geometries and combinations of materials, which make absolute measurements, using heat and mass transfer units, more difficult to measure and interpret. In this study we propose a heated, sweating cushion loading indenter to deliver controlled heat and water vapor transfer rates, allowing measurement of boundary conditions, which permits comparisons between products. This system permits both the measurement of the steady-state and transient conditions normally generated by the seated individual.

\section{METHODS}

\section{Specifications for Thermodynamic Rigid Cushion Loading Indenter}

The normal human body core temperature is about $37.5^{\circ} \mathrm{C}$. In still ambient conditions at $20^{\circ} \mathrm{C}$, skin surface temperature when clothed is between $31^{\circ} \mathrm{C}$ and $36^{\circ} \mathrm{C}$ [29]. For a resting individual, the total heat loss from a body surface area of $1.8 \mathrm{~m}^{2}$ is typically $64 \mathrm{~W} / \mathrm{m}^{2}\left(44 \mathrm{~W} / \mathrm{m}^{2}\right.$ sensible, $20 \mathrm{~W} / \mathrm{m}^{2}$ latent) and for heavy work, it is 
$244 \mathrm{~W} / \mathrm{m}^{2}$ (91 W/m $\mathrm{m}^{2}$ sensible, $153 \mathrm{~W} / \mathrm{m}^{2}$ latent) [29]. For a resting individual, the normal insensible moisture vapor flow through the skin per day is about $0.40 \mathrm{~kg} / \mathrm{m}^{2}$ [7]. In conditions of exertion, hot weather, high environmental humidity, or fever, active sweating accounts for a water flow of $>2.40 \mathrm{~kg} / \mathrm{m}^{2}$ per day [7]. These ranges may easily be produced with the immobilized patient. Studies on adult individuals seated at rest in wheelchairs in an outdoor environment showed a sensible heat loss in the pelvic-perineal area of $3 \mathrm{~g} / \mathrm{s}$.

Based on these studies, a thermodynamic rigid cushion loading indenter (TRCLI) was designed to operate at close to core temperature, delivering boundary conditions of $35{ }^{\circ} \mathrm{C}$ and relative humidity $(\mathrm{RH})$ of 80 percent on a standard foam block, loaded to $500 \mathrm{~N}$, at equilibrium. The loading conditions were chosen to match those specified in ISO 16840-2 [16] for testing the physical and mechanical characteristics of seat cushions and is considered to represent the load applied to a seat cushion by a $78 \mathrm{~kg}$ male. Figures 1 and 2 represent the system developed to meet these specifications.

\section{Description and Function of TRCLI}

An inner reservoir tank was formed by machining an aluminum-negative fiberglass mold according to the specifications for a rigid cushion loading indenter (RCLI) for the $13 \mathrm{~b}$ mold-form as specified in ISO 16840-2 [16]. The fiberglass vessel formed in this mold is watertight and was fitted with two inlet and two outlet pipe fittings to receive circulating water at a controlled temperature. The tank was filled with spherical glass flow dispersers (marbles) nominally $15 \mathrm{~mm}$ in diameter. Water was supplied to the tank through a closed circuit recirculating heater unit (Forma Scientific, model 2095, Bath and Circulator; Marietta, Ohio) at a flow rate of $0.8 \mathrm{~L} / \mathrm{min}$. The temperature of the water in the recirculator was controlled at a set point of $37.5^{\circ} \mathrm{C} \pm 0.2^{\circ} \mathrm{C}$.

An outer shell was vacuum-formed from $4 \pm 1 \mathrm{~mm}$ polycarbonate sheet (Figure 1) over a positive shape mold produced according to the specifications for an RCLI with the inner surface of the shell formed from an enlarged version of the 13b shape with the dimensions in Table 1 and according to the fabrication instructions specified in ISO 16840-2 [16]. The shell was perforated (diameter $2.3 \mathrm{~mm}$ ) between the pubic symphysis and the region associated with the ischial tuberosities (ITs) to provide areas for moisture vapor transfer, as illustrated in Figure 2.

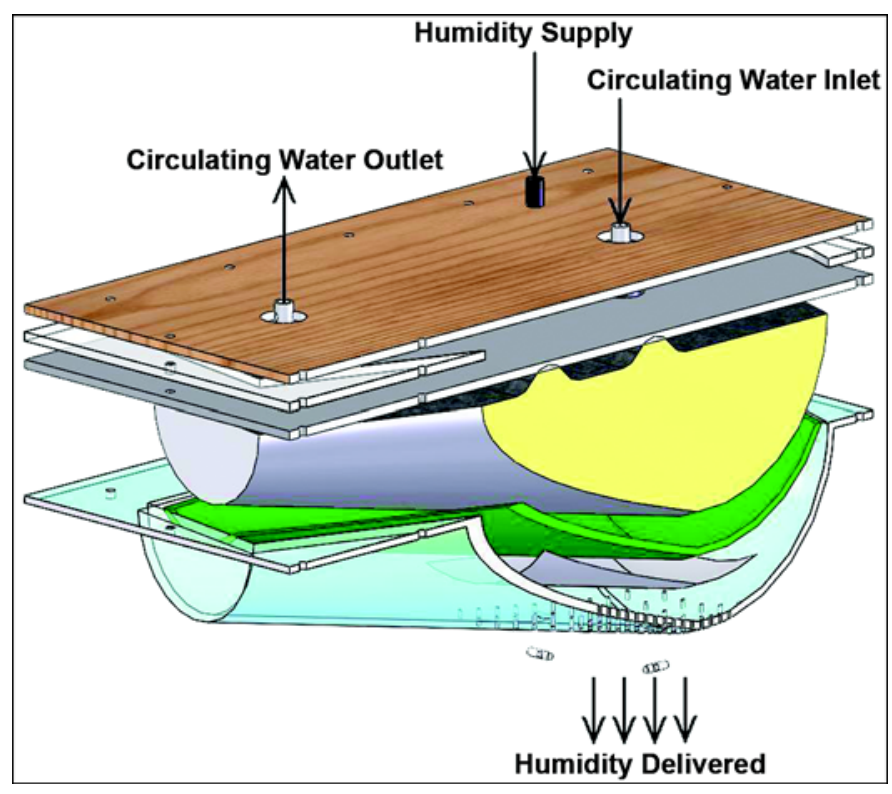

Figure 1.

Diagrammatic expanded view of thermodynamic rigid cushion loading indenter (TRCLI). Expanded cross-sectional view of circulation of water within tank of TRCLI and location of microporous water vapor permeable membrane (gray), capillary matting (green), and outer polycarbonate shell (blue).

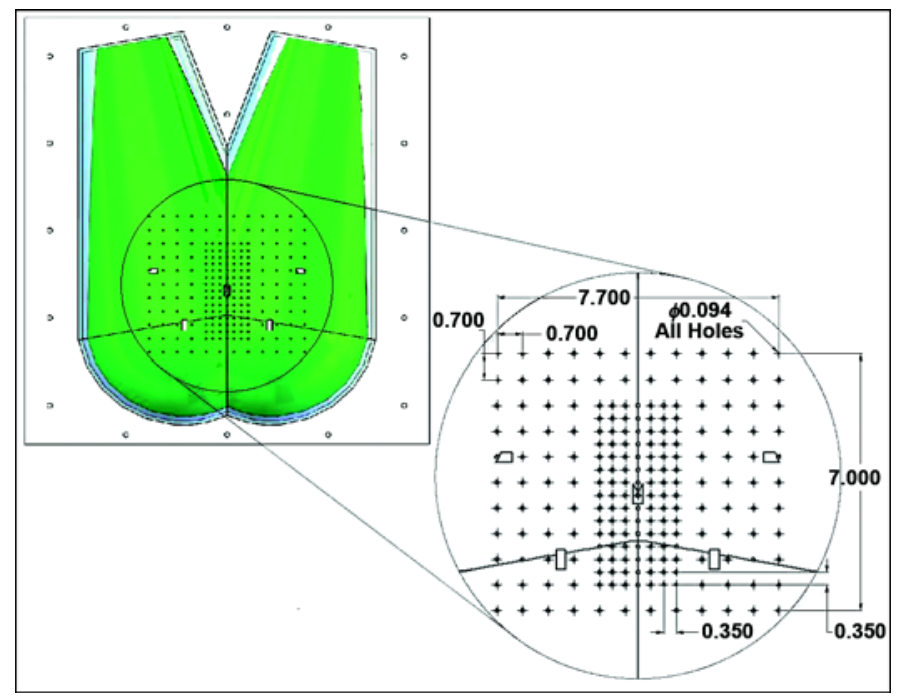

Figure 2.

Distribution of perforations between ischial tuberosities and symphysis pubis regions of outer shell of thermodynamic rigid cushion loading indenter and location of sensors on outer shell. $\varphi=$ diameter.

The density of the perforations was greater in the perineal region, because this area has been reported to have a higher rate of sweating [30]. 
JRRD, Volume 46, Number 7, 2009

Table 1.

Dimensions for conical sections required to fabricate outer shell according to ISO specifications. ${ }^{*}$

\begin{tabular}{|c|c|c|c|c|c|c|c|c|c|c|c|}
\hline $\begin{array}{c}\text { ISO } \\
\text { Indenter } \\
\text { Model }\end{array}$ & $\begin{array}{c}\text { Indenter } \\
\text { Width } \\
\text { (mm) }\end{array}$ & $\begin{array}{c}\text { Overall } \\
\text { Length } \\
\text { (mm) }\end{array}$ & $\begin{array}{c}\text { Distance } \\
\text { Between } \\
\text { ITs (mm) }\end{array}$ & $\begin{array}{c}\text { Cone } \\
\text { Angle } \\
\left({ }^{\circ}\right)\end{array}$ & $\begin{array}{c}\text { Cone Width } \\
\text { at First } \\
\text { Cut (mm) }\end{array}$ & $\begin{array}{c}\text { Cone Height } \\
\text { Without } \\
\text { Sphere (mm) }\end{array}$ & $\begin{array}{c}\text { Height } \\
\text { with Sphere } \\
(\mathrm{mm})\end{array}$ & $\begin{array}{c}\text { Height } \\
\text { Without } \\
\text { Sphere (mm) }\end{array}$ & $\begin{array}{c}\text { Major } \\
\text { Diameter of } \\
\text { Cone }(\mathrm{mm})\end{array}$ & $\begin{array}{c}\text { Minor } \\
\text { Diameter of } \\
\text { Cone }(\mathrm{mm})\end{array}$ & $\begin{array}{c}\text { Length of } \\
\text { Cone Edge } \\
\text { (mm) }\end{array}$ \\
\hline Enlarged & 390 & 500 & 137 & 120 & 10 & 195 & 357 & 495 & 274 & 148 & 363 \\
\hline Regular (13b) & 360 & 500 & 127 & 110 & 10 & 180 & 367 & 494 & 254 & 124 & 373 \\
\hline
\end{tabular}

A microporous water vapor-permeable membrane GORE-TEX laminate $\left(5 \mathrm{l} / 24 \mathrm{~h} / \mathrm{m}^{2}\right)$ was glued to the inside surface of the perforated region of the outer shell. A capillary mat (Nortene PNI0102 horticultural capillary matting, Capital Gardens; London, United Kingdom; 0.28 kg/ $\mathrm{m}^{2}$, dry thickness $2.6 \mathrm{~mm}$ ) was shaped to conform to the shape of the RCLI shell. The outer shell was bolted with a rubber gasket to the tank. The gap between the inner and outer shells was charged with a fixed aliquot of water that was able to gradually diffuse across the water vaporpermeable membrane and through the perforations. The capillary matting ensured that the water was dispersed across the perforated region of the TRCLI.

This assembly was attached to a pneumatic piston in a loading rig to enable a controlled load of $300 \mathrm{~N}$ to be applied at a pointed defined by the intersection of the centerline and the join between the buttock and thigh conical sections. The cushion was positioned so that the rear edge of the cushion was $125 \mathrm{~mm}$ behind the point of loading on the TRCLI (Figure 3).

\section{Sensors}

Single-chip complementary metal-oxide semiconductor temperature and humidity sensors (SHT75, Sensirion AG; Staefa, Switzerland) were attached to the outer surface of the outer shell in the positions corresponding to the left and right thigh, left and right ITs, and the perineal area (Figure 2). These sensors provide accuracy of $\pm 0.3^{\circ} \mathrm{C}$ at $25^{\circ} \mathrm{C}$ and \pm 1.8 percent $\mathrm{RH}(0 \%-100 \%$ range).

The testing environment was controlled to be $21{ }^{\circ} \mathrm{C} \pm$ $0.5^{\circ} \mathrm{C}$ and $50 \pm 5$ percent $\mathrm{RH}$.

\section{Calibration of Temperature Sensors}

The temperature sensors are precalibrated by the manufacturer, because they cannot be calibrated using conventional fixed-point immersion techniques. The humidity sensors' calibration was verified by placing them first in a closed environment with a saturated salt solution at $25^{\circ} \mathrm{C}$ that generated 75 percent $\mathrm{RH}$ [31] and then in the same

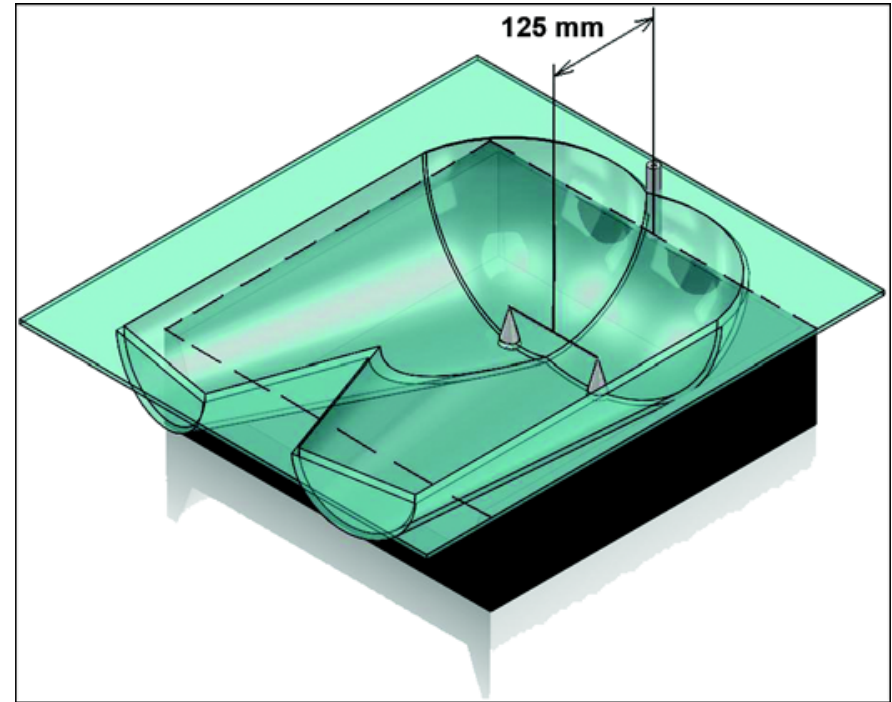

Figure 3.

Relative position of cushion and loading surface of thermodynamic rigid cushion loading indenter.

closed environment with a diatomaceous earth desiccant (W. A. Hammond, Drierite; Xenia, Ohio).

\section{Verification of TRCLI}

The TRCLI was suspended in the room with minimal air movement and allowed to equilibrate, then the internal temperature was confirmed to be in the range $37.5^{\circ} \mathrm{C} \pm$ $0.5^{\circ} \mathrm{C}$. Deviation from these values was likely to be a consequence of poor water flow or mixing.

\section{Repeatability}

The environmental conditions of the test required that the room temperature and $\mathrm{RH}$ be maintained within the range $21{ }^{\circ} \mathrm{C} \pm 0.5^{\circ} \mathrm{C}$ and $50 \pm 5$ percent $\mathrm{RH}$. The TRCLI was allowed to equilibrate by suspending it free in air ( $60 \pm$ $5 \mathrm{~min}$ ) and then bringing it into contact with a plain, uncovered $100 \mathrm{~mm}$-thick resilient polyurethane cushion (HR70) for $2 \mathrm{~h}$. Readings from the temperature and 
humidity sensors were taken automatically every $3 \mathrm{~s}$. The TRCLI was then removed from the cushion for at least $12 \mathrm{~h}$ before repeating the test. The test was repeated nine times.

\section{Cushion Testing}

A selection of 32 internationally representative, commercially available, unused wheelchair cushions were obtained by inviting donations of different products from manufacturers as part of the United Kingdom National Health Service (NHS) Centres for Evidence-Based Purchasing (CEP) program. We employed a limit of two cushions from each manufacturer to encourage product diversity and to limit the size of the study. Prior to testing, the cushions were preconditioned according to the protocol specified in ISO IS16840-2 [16].

The TRCLI was allowed to hang in air until it reached equilibrium ( $60 \pm 5 \mathrm{~min}$ ). The surface temperature hanging in air was recorded. Then it was placed on the cushion under a load of $300 \mathrm{~N}$.

\section{Statistical Methods for Clustering Cushions with Similar Properties}

To identify which of the parameters derived from the contact temperature and humidity measurements are most influential in differentiating wheelchair cushions into classes according to their heat and moisture dissipation characteristics, we performed a cluster analysis on the data from the 32 cushions tested.

Initially, we performed an agglomerative hierarchical cluster analysis using SPSS version 15.01 (Chicago, Illinois) (November 2006). A squared Euclidean distance interval measure was used employing Ward's method. Variables were standardized with Z-scores. This approach enabled us to perform analysis to determine the optimum number of clusters from the data obtained. We performed cluster analysis separately for each of the anatomical sites on the TRCLI (thigh, IT, and perineum), as well as by grouping all the sites into a combined measure. We found that the data could be successfully represented by two distinct clusters, consistently, for all three anatomical sites and for the combined dataset.

We then performed a two-step cluster analysis providing more detailed information about the contribution made to the clusters by the separate variables. The mean values of all the parameters used to form the clusters were also calculated, and estimates of the confidence intervals of the means of each parameter for each cluster were plotted.

\section{RESULTS}

\section{Classification of Cushion Properties}

The material used to construct the cushion was classified into four material types: air, foam, gel, and viscofoam. Additional subclassifications (such as "solid gel" and "viscous fluid") are desirable but we did not adopt them in the analysis to retain statistical power. We felt that such differences would be small in their thermodynamic effect, even though they have significant influence on mechanical support characteristics. In some cases, the cushions were constructed from multiple material components close to the surface and were classified as "composite." The cushions were also classified according to their shape: "flat" and "contoured." The covering materials used were also classified into three groups: "fabric," "polyurethane," and "none." The number of cushions in each category of properties is summarized in Table 2.

\section{Repeatability on HR70 Polyurethane Foam Cushion}

Table 3 summarizes the mean \pm standard deviation results obtained from nine tests for repeatability representing parameters extracted from the test data at the IT region of the TRCLI.

\section{Influence of Site on TRCLI for Measurements of Mean Heat and Moisture Dissipation Parameters}

One of the design features of the TRCLI is the means to measure at different anatomical locations with the added provision for controlling the rate of delivery of water vapor

Table 2.

Classification of cushions under evaluation.

\begin{tabular}{lc}
\hline Property & $\begin{array}{c}\text { Number of } \\
\text { Cushions Tested }\end{array}$ \\
\hline Core Material & 12 \\
Foam & 6 \\
Gel & 9 \\
Viscofoam & 5 \\
Air & \\
Construction & 27 \\
Uniform & 5 \\
Composite & \\
Shape & 27 \\
Flat & 5 \\
Contoured & \\
Cover & 7 \\
Fabric & 21 \\
Polyurethane & 4 \\
None & \\
\hline \hline
\end{tabular}


through different perforation densities in the outer shell. In addition, the degree of cushion compression, the geometry of the outer shell, and characteristics of the cushion (e.g., use of composite construction or surface contouring) were expected to influence the values obtained for the parameters of interest. The analysis of variance (ANOVA) results (Table 4) suggest that significant differences exist in the temperature readings obtained at different anatomical sites but not in the $\mathrm{RH}$ readings.

A two-step cluster analysis grouped the cushions into two clusters, each having similar thermodynamic properties. The results for the measurements at the ITs of the TRCLI are summarized in Table 5. However, when we performed an ANOVA to determine which parameters were significantly different in the two clusters of cushions, the influence of the anatomical location of measurement was not particularly significant. The role of each parameter in defining the clusters is most apparent in the combined dataset.

Table 6 summarizes the characteristics of the two clusters generated for each model.

\section{Cushion Construction Characteristics}

We analyzed the relationship between the cushion property and the cluster to which the cushion was assigned using the two-step cluster analysis and tested the significance of the association between a cushion property and its assigned cluster using the $\chi^{2}$ statistic. Table 7 summarizes the results and indicates only isolated instances in which cushion properties are associated with cluster membership. These results may be influenced by the unequal group sizes for the cushion properties.

However, analysis that does not attempt to categorize cushions into clusters reveals more detail. We performed an ANOVA for each of the variables tested using data from the sensors in the IT region of the TRCLI for each cushion characteristic (Table 8). Using the simple grouping of cushion material characteristics, we can infer some practical guidelines for cushion design. The cushion cover did not appear to influence any of the heat and water vapor dissipation parameters used in this study. The core material used was associated with differences in

Table 3.

Repeatability test results for IT region for each variable extracted from the temperature/humidity versus time data using HR70 flat polyurethane cushion, uncovered.

\begin{tabular}{|c|c|c|c|c|c|c|c|c|c|c|c|c|}
\hline \multirow{2}{*}{ Test } & \multicolumn{3}{|c|}{ Mean $\left({ }^{\circ} \mathbf{C}\right)$} & \multicolumn{3}{|c|}{ Mean Differences $\left({ }^{\circ} \mathrm{C}\right)$} & \multicolumn{3}{|c|}{ Mean (\% RH) } & \multicolumn{3}{|c|}{ Mean Differences (\% RH) } \\
\hline & $\mathbf{T}_{\mathbf{0}}$ & $T_{1}$ & $\mathbf{T}_{2}$ & $T_{1-0}$ & $\mathbf{T}_{2-0}$ & $T_{2-1}$ & $\mathbf{H}_{\mathbf{0}}$ & $\mathbf{H}_{1}$ & $\mathbf{H}_{2}$ & $\mathbf{H}_{1-0}$ & $\mathbf{H}_{2-0}$ & $\mathrm{H}_{2-1}$ \\
\hline Mean & 29.0 & 34.3 & 35.0 & 5.37 & 6.07 & 0.704 & 41.7 & 55.95 & 54.06 & 14.23 & 25.1 & -0.89 \\
\hline SD & 0.47 & 0.51 & 0.38 & 0.48 & 0.43 & 0.14 & 1.05 & 1.33 & 1.68 & 1.55 & 1.91 & 1.08 \\
\hline
\end{tabular}

$\mathrm{H}_{0}=$ relative humidity (\%) at time of contact between TRCLI and cushion, $\mathrm{H}_{1}=$ relative humidity (\%) $1 \mathrm{~h}$ after contact, $\mathrm{H}_{2}=$ relative humidity (\%) $2 \mathrm{~h}$ after contact, $\mathrm{H}_{1-0}=$ relative humidity difference (\%) between $1 \mathrm{~h}$ and time of contact $\left(\mathrm{H}_{1}-\mathrm{H}_{0}\right), \mathrm{H}_{2-0}=$ relative humidity difference (\%) between $2 \mathrm{~h}$ and time of contact $\left(\mathrm{H}_{2}-\mathrm{H}_{0}\right)$, $\mathrm{H}_{2-1}=$ relative humidity difference $(\%)$ between $2 \mathrm{~h}$ and $1 \mathrm{~h}$ after contact $\left(\mathrm{H}_{2}-\mathrm{H}_{1}\right)$, IT = ischial tuberosity, $\mathrm{RH}=$ relative humidity, $\mathrm{SD}=$ standard deviation, $\mathrm{T}_{0}=$ temperature $\left({ }^{\circ} \mathrm{C}\right)$ at time of contact between TRCLI and cushion, $\mathrm{T}_{1}=$ temperature $\left({ }^{\circ} \mathrm{C}\right) 1 \mathrm{~h}$ after contact, $\mathrm{T}_{2}=$ temperature $\left({ }^{\circ} \mathrm{C}\right) 2 \mathrm{~h}$ after contact, $\mathrm{T}_{1-0}=$ temperature difference $\left({ }^{\circ} \mathrm{C}\right)$ between $1 \mathrm{~h}$ and time of contact $\left(\mathrm{T}_{1}-\mathrm{T}_{0}\right), \mathrm{T}_{2-0}=$ temperature difference $\left({ }^{\circ} \mathrm{C}\right)$ between $2 \mathrm{~h}$ and time of contact $\left(\mathrm{T}_{2}-\mathrm{T}_{0}\right)$, $\mathrm{T}_{2-1}=$ temperature difference $\left({ }^{\circ} \mathrm{C}\right)$ between $2 \mathrm{~h}$ and $1 \mathrm{~h}$ after contact $\left(\mathrm{T}_{2}-\mathrm{T}_{1}\right)$, TRCLI $=$ thermodynamic rigid cushion loading indenter.

Table 4.

Results from analysis of variance to determine whether heat and moisture dissipation values differ with site of measurement.

\begin{tabular}{|c|c|c|c|c|c|c|c|c|c|}
\hline \multirow{2}{*}{$\begin{array}{c}\text { Measurement } \\
\text { Site }\end{array}$} & \multicolumn{3}{|c|}{ Heat Dissipation (Mean \pm SD) } & \multicolumn{3}{|c|}{ Mean Difference \pm SD } & \multicolumn{3}{|c|}{ Moisture Dissipation (Mean \pm SD) } \\
\hline & $\mathbf{T}_{1}{ }^{*}\left({ }^{\circ} \mathbf{C}\right)$ & $\mathrm{H}_{1}(\% \mathrm{RH})$ & $\mathbf{T}_{2}{ }^{*}\left({ }^{\circ} \mathbf{C}\right)$ & $\mathrm{H}_{2}(\% \mathrm{RH})$ & $\mathrm{T}_{1-0}\left({ }^{\circ} \mathrm{C}\right)$ & $\mathrm{H}_{1-0}(\% \mathrm{RH})$ & $\mathrm{T}_{2-1}{ }^{*}\left({ }^{\circ} \mathrm{C}\right)$ & $\mathrm{H}_{2-1}(\% \mathrm{RH})$ & $\mathrm{T}_{2-0}{ }^{*}\left({ }^{\circ} \mathrm{C}\right)$ \\
\hline $\mathrm{Im}_{\mathrm{SH}}$ & $33.8 \pm 1.3$ & $47.9 \pm 9.2$ & $34.8 \pm 1.1$ & $48.3 \pm 11.3$ & $5.4 \pm 1.2$ & $8.2 \pm 7.7$ & $0.98 \pm 0.40$ & $0.39 \pm 2.6$ & $6.4 \pm 1.2$ \\
\hline Perineum & $36.9 \pm 1.1$ & $50.4 \pm 13.2$ & $37.3 \pm 0.78$ & $52.2 \pm 14.3$ & $4.9 \pm 1.0$ & $13.4 \pm 9.8$ & $0.43 \pm 0.41$ & $1.9 \pm 1.9$ & $5.4 \pm 0.89$ \\
\hline
\end{tabular}

${ }^{*}$ Parameter significant at $p<0.001$.

$\mathrm{H}_{0}=$ relative humidity (\%) at time of contact between TRCLI and cushion, $\mathrm{H}_{1}=$ relative humidity (\%) $1 \mathrm{~h}$ after contact, $\mathrm{H}_{2}=$ relative humidity (\%) $2 \mathrm{~h}$ after contact, $\mathrm{H}_{1-0}=$ relative humidity difference (\%) between $1 \mathrm{~h}$ and time of contact $\left(\mathrm{H}_{1}-\mathrm{H}_{0}\right), \mathrm{H}_{2-0}=$ relative humidity difference (\%) between $2 \mathrm{~h}$ and time of contact $\left(\mathrm{H}_{2}-\mathrm{H}_{0}\right)$, $\mathrm{H}_{2-1}=$ relative humidity difference $(\%)$ between $2 \mathrm{~h}$ and $1 \mathrm{~h}$ after contact $\left(\mathrm{H}_{2}-\mathrm{H}_{1}\right)$, IT = ischial tuberosity, $\mathrm{RH}=$ relative humidity, $\mathrm{SD}=$ standard deviation, $\mathrm{T}_{0}=$ temperature $\left({ }^{\circ} \mathrm{C}\right)$ at time of contact between TRCLI and cushion, $\mathrm{T}_{1}=$ temperature $\left({ }^{\circ} \mathrm{C}\right) 1 \mathrm{~h}$ after contact, $\mathrm{T}_{2}=$ temperature $\left({ }^{\circ} \mathrm{C}\right) 2 \mathrm{~h}$ after contact, $\mathrm{T}_{1-0}=$ temperature difference $\left({ }^{\circ} \mathrm{C}\right)$ between $1 \mathrm{~h}$ and time of contact $\left(\mathrm{T}_{1}-\mathrm{T}_{0}\right), \mathrm{T}_{2-0}=$ temperature difference $\left({ }^{\circ} \mathrm{C}\right)$ between $2 \mathrm{~h}$ and time of contact $\left(\mathrm{T}_{2}-\mathrm{T}_{0}\right), \mathrm{T}_{2-1}=$ temperature difference $\left({ }^{\circ} \mathrm{C}\right)$ between $2 \mathrm{~h}$ and $1 \mathrm{~h}$ after contact $\left(\mathrm{T}_{2}-\mathrm{T}_{1}\right)$, TRCLI $=$ thermodynamic cushion loading indenter. 
heat and water vapor parameters associated with the first hour of loading. Composite construction did influence heat dissipation. Contoured construction did not influence heat or water vapor dissipation.

\section{Properties of Proposed Classification System}

Although the models only significantly differentiated two distinct clusters, it is interesting to test the potential of these data to define four clusters. Four clusters would classify cushions according to the conceptual "classification table" in Table 5. If four groupings of cushions are proposed, it is then interesting to determine whether heat and moisture dissipation threshold values can be established to classify cushions. Figure 4 illustrates the "combined sites" cluster model if the two-step cluster analysis is forced to generate four clusters from the $1 \mathrm{~h}$ temperature and humidity data.

The $1 \mathrm{~h}$ data was chosen because no sensor failures occurred at $1 \mathrm{~h}$. Sensor failure causes the cluster analysis to exclude that cushion from the analysis completely, which with the "forced" four-cluster model, would further weaken the statistical power of the analysis and the generalizability of the results.

The confidence intervals indicate that Clusters 1 and 3 in terms of temperature at $1 \mathrm{~h}$ and Clusters 2 and 4 in terms of moisture dissipation can be significantly differentiated. We elected to define the thresholds for "high" and "low" by using the boundaries of the upper and lower quartiles of temperature and humidity measurements of the IT sensors after $1 \mathrm{~h}$ (Table 9).

Cushions that produced a temperature below $34^{\circ} \mathrm{C}$ after $1 \mathrm{~h}$ were classified as "high heat dissipaters" and above $36.5^{\circ} \mathrm{C}$, "low heat dissipaters." Cushions producing a $\mathrm{RH}$

\section{Table 5.}

Conceptual classification table for four thermal characteristics labeled according to the results of force two-step cluster analysis.

\begin{tabular}{l|c|c|}
\hline Property & High Dissipation & Low Dissipation \\
\hline Heat & Cluster 3 & Cluster 1 \\
\cline { 2 - 3 } Moisture & Cluster 2 & Cluster 4 \\
\hline \hline
\end{tabular}

Table 6.

Parameter values in Cluster 1 relative to Cluster 2 (two-step analysis). Summary of mean \pm SD ( $n$ in cluster) values for each cluster model (created from data generated at each anatomical site, plus combined data set model).

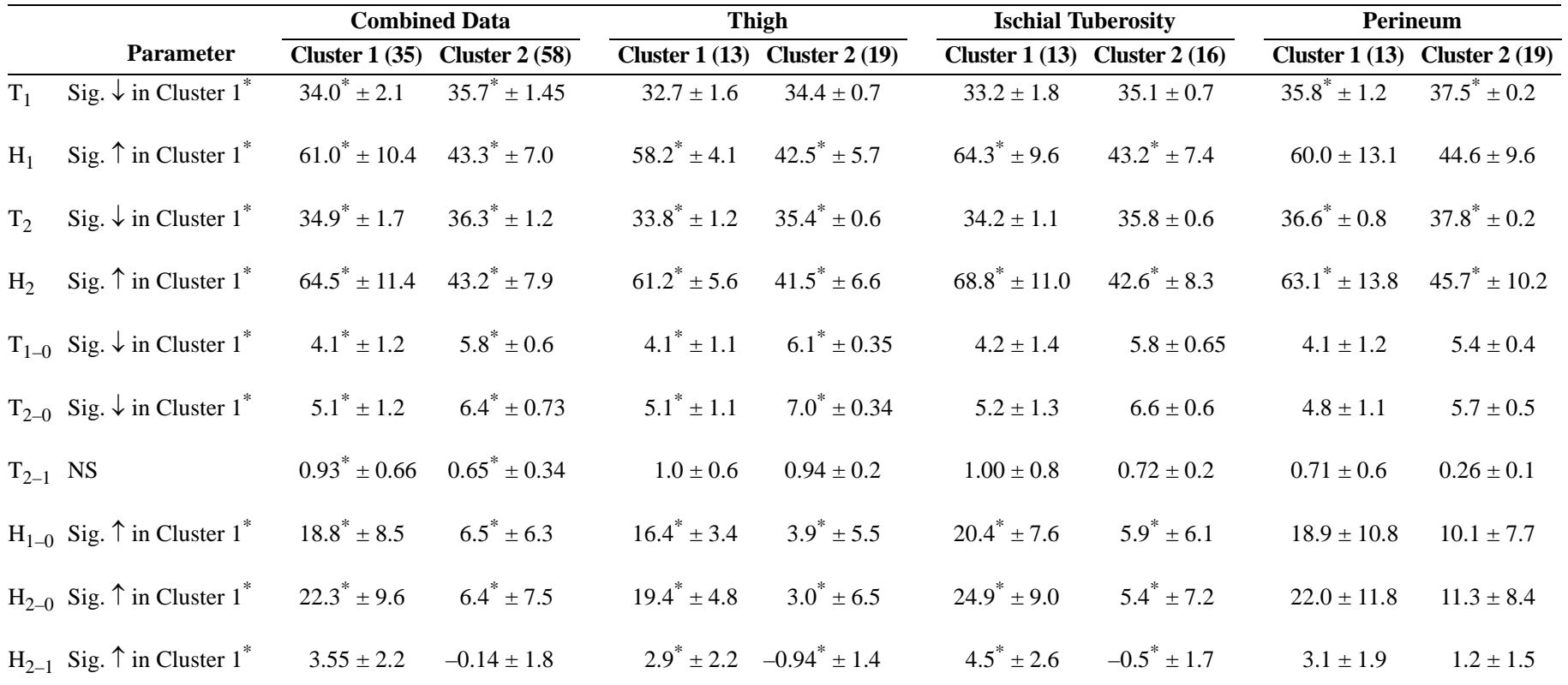

Note: Overall contribution made by each variable is summarized in Column 1 and those instances in which variable in Cluster 1 differs significantly from Cluster 2 for majority of anatomical sites are marked with “*.” Arrow indicates whether Cluster 1 tends to be relatively higher $(\uparrow)$ or lower $(\downarrow)$ than Cluster 2.

$\mathrm{H}_{0}=$ relative humidity (\%) at time of contact between TRCLI and cushion, $\mathrm{H}_{1}=$ relative humidity (\%) $1 \mathrm{~h}$ after contact, $\mathrm{H}_{2}$ = relative humidity (\%) $2 \mathrm{~h}$ after contact, $\mathrm{H}_{1-0}=$ relative humidity difference (\%) between $1 \mathrm{~h}$ and time of contact $\left(\mathrm{H}_{1}-\mathrm{H}_{0}\right), \mathrm{H}_{2-0}=$ relative humidity difference (\%) between $2 \mathrm{~h}$ and time of contact $\left(\mathrm{H}_{2}-\mathrm{H}_{0}\right), \mathrm{H}_{2-1}=$ relative humidity difference $(\%)$ between $2 \mathrm{~h}$ and $1 \mathrm{~h}$ after contact $\left(\mathrm{H}_{2}-\mathrm{H}_{1}\right)$, NS = not significant, Sig. $=$ significance, $\mathrm{T}_{0}=$ temperature $\left({ }^{\circ} \mathrm{C}\right)$ at time of contact between TRCLI and cushion, $\mathrm{T}_{1}=$ temperature $\left({ }^{\circ} \mathrm{C}\right) 1 \mathrm{~h}$ after contact, $\mathrm{T}_{2}=$ temperature $\left({ }^{\circ} \mathrm{C}\right) 2 \mathrm{~h}$ after contact, $\mathrm{T}_{1-0}=$ temperature difference $\left({ }^{\circ} \mathrm{C}\right)$ between $1 \mathrm{~h}$ and time of contact $\left(\mathrm{T}_{1}-\mathrm{T}_{0}\right), \mathrm{T}_{2-0}=$ temperature difference $\left({ }^{\circ} \mathrm{C}\right)$ between $2 \mathrm{~h}$ and time of contact $\left(\mathrm{T}_{2}-\mathrm{T}_{0}\right)$, $\mathrm{T}_{2-1}=$ temperature difference $\left({ }^{\circ} \mathrm{C}\right)$ between $2 \mathrm{~h}$ and $1 \mathrm{~h}$ after contact $\left(\mathrm{T}_{2}-\mathrm{T}_{1}\right)$. 
JRRD, Volume 46, Number 7, 2009

Table 7.

Relative insignificance of importance of cushion characteristics in determining cluster competition. Two-step cluster model from measurements at each anatomical site.

\begin{tabular}{|c|c|c|c|c|c|c|c|c|}
\hline \multirow{2}{*}{ Cushion Property } & \multicolumn{2}{|c|}{ Combined } & \multicolumn{2}{|c|}{ Thigh } & \multicolumn{2}{|c|}{ IT* } & \multicolumn{2}{|c|}{ Perineum } \\
\hline & Cluster 1 & Cluster 2 & Cluster 1 & Cluster 2 & Cluster 1 & Cluster 2 & Cluster 1 & Cluster 2 \\
\hline \multicolumn{9}{|l|}{ Contoured } \\
\hline Yes & 8 & 6 & 4 & 1 & 3 & 1 & 3 & 2 \\
\hline No & 27 & 52 & 9 & 18 & 10 & 15 & 10 & 17 \\
\hline \multicolumn{9}{|l|}{ Cover Material } \\
\hline Fabric & 14 & 6 & 5 & 2 & 4 & 2 & 5 & 2 \\
\hline Polyurethane & 20 & 41 & 8 & 13 & 7 & 12 & 8 & 13 \\
\hline None & 1 & 11 & 0 & 4 & 2 & 2 & 0 & 4 \\
\hline \multicolumn{9}{|l|}{ Core Material } \\
\hline Gel & $17^{\dagger}$ & 0 & 5 & 1 & 5 & 0 & 6 & 0 \\
\hline Foam & 4 & 31 & 1 & 11 & 3 & 8 & 2 & 10 \\
\hline Viscofoam & 0 & 27 & 2 & 7 & 1 & 8 & 0 & 9 \\
\hline Air & 14 & 0 & 5 & 0 & 4 & 0 & 5 & 0 \\
\hline \multicolumn{9}{|l|}{ Composite } \\
\hline Yes & $13^{\dagger}$ & 22 & 4 & 1 & 3 & 0 & 5 & 0 \\
\hline No & 0 & 58 & 9 & 18 & 10 & 16 & 8 & 19 \\
\hline
\end{tabular}

${ }^{*}$ For IT cluster analysis, three cases were excluded because of humidity sensor failure. Cushion types affected were one each of gel, air, and viscofoam.

†Instances in which cushion composition is significant determinant of cluster in which to classify thermodynamic performance of cushion.

IT $=$ ischial tuberosity.

Table 8.

Results from analysis of variance to determine whether cushion composition influences heat and moisture dissipation for IT region of TRCLI.

\begin{tabular}{|c|c|c|c|c|c|c|c|c|c|c|}
\hline \multirow{2}{*}{$\begin{array}{l}\text { Cushion } \\
\text { Property }\end{array}$} & \multicolumn{5}{|c|}{ Direct Measurement (mean \pm SD) } & \multicolumn{5}{|c|}{ Difference Measure (mean \pm SD) } \\
\hline & $\mathrm{T}_{1}\left({ }^{\circ} \mathrm{C}\right)$ & $\mathrm{H}_{1}(\% \mathrm{RH})$ & $\mathrm{T}_{2}\left({ }^{\circ} \mathrm{C}\right)$ & $\mathbf{H}_{2}(\% \mathbf{R H})$ & $\mathrm{T}_{1-0}\left({ }^{\circ} \mathrm{C}\right)$ & $\overline{\mathrm{H}_{1-0}(\% \mathrm{RH})}$ & $\mathrm{T}_{2-1}\left({ }^{\circ} \mathrm{C}\right)$ & $\mathrm{H}_{2-1}(\% \mathrm{RH})$ & $\mathrm{T}_{2-0}\left({ }^{\circ} \mathrm{C}\right)$ & $\mathrm{H}_{2-0}(\% \mathrm{RH})$ \\
\hline \multicolumn{11}{|l|}{ Cover } \\
\hline Fabric & $33.9 \pm 2.4$ & $53.0 \pm 15.0$ & $35.0 \pm 1.9$ & $55.8 \pm 16.9$ & $4.5 \pm 1.1$ & $12.6 \pm 9.7$ & $1.1 \pm 0.63$ & $2.8 \pm 2.5$ & $5.6 \pm 0.9$ & $15.4 \pm 11.7$ \\
\hline Polyurethane & $35.3 \pm 1.6$ & $49.1 \pm 10.8$ & $36.0 \pm 1.3$ & $50.0 \pm 12.7$ & $5.3 \pm 1.1$ & $11.0 \pm 8.9$ & $0.7 \pm 0.4$ & $0.9 \pm 2.5$ & $6.0 \pm 1.2$ & $11.9 \pm 10.9$ \\
\hline None & $35.8 \pm 1.4$ & $47.9 \pm 11.9$ & $36.2 \pm 1.2$ & $48.1 \pm 13.4$ & $5.8 \pm 0.6$ & $8.4 \pm 10.7$ & $0.4 \pm 0.3$ & $0.2 \pm 2.4$ & $6.2 \pm 0.9$ & $8.6 \pm 12.4$ \\
\hline Significance & NS & NS & NS & NS & NS & NS & NS & NS & NS & NS \\
\hline \multicolumn{11}{|l|}{ Core } \\
\hline Gel & $33.0 \pm 2.1$ & $57.2 \pm 11.9$ & $34.5 \pm 1.8$ & $60.7 \pm 13.2$ & $4.1 \pm 1.2$ & $15.2 \pm 8.1$ & $1.4 \pm 0.4$ & $3.5 \pm 2.2$ & $5.6 \pm 1.0$ & $18.8 \pm 9.6$ \\
\hline Foam & $35.7 \pm 1.5$ & $47.0 \pm 10.7$ & $36.3 \pm 1.2$ & $46.9 \pm 12.0$ & $5.5 \pm 1.0$ & $9.1 \pm 8.6$ & $0.6 \pm 0.4$ & $-0.1 \pm 2.0$ & $6.1 \pm 1.0$ & $9.1 \pm 10.0$ \\
\hline Viscofoam & $35.4 \pm 1.6$ & $42.4 \pm 6.7$ & $36.1 \pm 1.3$ & $42.7 \pm 7.9$ & $5.8 \pm 0.5$ & $6.2 \pm 6.8$ & $0.7 \pm 0.4$ & $0.3 \pm 2.1$ & $6.5 \pm 0.6$ & $6.5 \pm 8.5$ \\
\hline Air & $35.2 \pm 1.5$ & $62.0 \pm 8.7$ & $35.5 \pm 1.4$ & $65.4 \pm 10.6$ & $4.5 \pm 1.3$ & $19.8 \pm 8.8$ & $0.3 \pm 0.2$ & $3.3 \pm 2.5$ & $4.8 \pm 1.4$ & $23.2 \pm 10.4$ \\
\hline Significance & $*$ & $\dagger$ & $*$ & $\dagger$ & NS & NS & * & * & NS & NS \\
\hline \multicolumn{11}{|l|}{ Composite } \\
\hline Uniform & $35.4 \pm 1.7$ & $48.1 \pm 11.0$ & $36.0 \pm 1.3$ & $49.0 \pm 12.9$ & $5.4 \pm 1.0$ & $10.0 \pm 9.0$ & $0.7 \pm 0.4$ & $0.8 \pm 2.5$ & $6.1 \pm 1.1$ & $10.9 \pm 10.9$ \\
\hline Composite & $33.1 \pm 2.1$ & $60.1 \pm 12.6$ & $34.3 \pm 1.8$ & $63.5 \pm 13.6$ & $3.9 \pm 1.1$ & $17.3 \pm 9.2$ & $1.2 \pm 0.6$ & $3.4 \pm 2.3$ & $5.0 \pm 1.1$ & $20.7 \pm 10.6$ \\
\hline Significance & $*$ & NS & $*$ & NS & $*$ & NS & NS & NS & NS & NS \\
\hline \multicolumn{11}{|l|}{ Shape } \\
\hline Flat & $35.2 \pm 1.8$ & $49.1 \pm 12.3$ & $35.9 \pm 1.5$ & $50.0 \pm 14.2$ & $5.2 \pm 1.2$ & $10.5 \pm 9.6$ & $0.7 \pm 0.4$ & $0.8 \pm 2.5$ & $5.9 \pm 1.2$ & $11.3 \pm 11.6$ \\
\hline Contoured & $34.2 \pm 2.3$ & $53.2 \pm 9.5$ & $35.3 \pm 1.7$ & $56.6 \pm 10.6$ & $4.8 \pm 1.1$ & $14.1 \pm 6.7$ & $1.2 \pm 0.6$ & $3.4 \pm 2.2$ & $6.0 \pm 0.7$ & $17.6 \pm 8.0$ \\
\hline Significance & NS & NS & NS & NS & NS & NS & NS & NS & NS & NS \\
\hline
\end{tabular}

*Significant at $p<0.001$.

${ }^{\dagger}$ Significant at $p<0.01$.

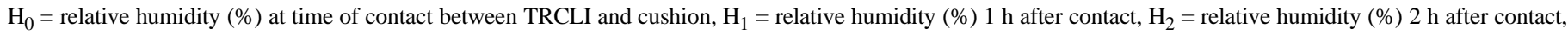

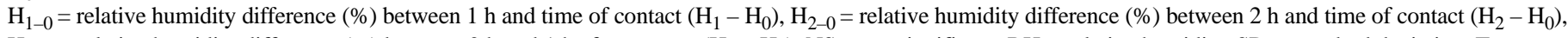

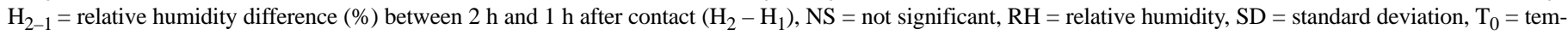

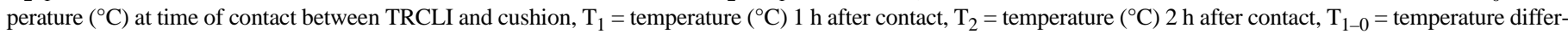

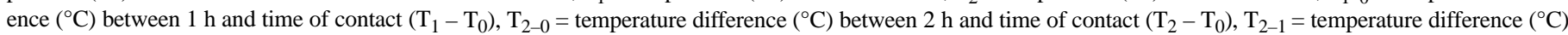
between $2 \mathrm{~h}$ and $1 \mathrm{~h}$ after contact $\left(\mathrm{T}_{2}-\mathrm{T}_{1}\right)$. 
(a)

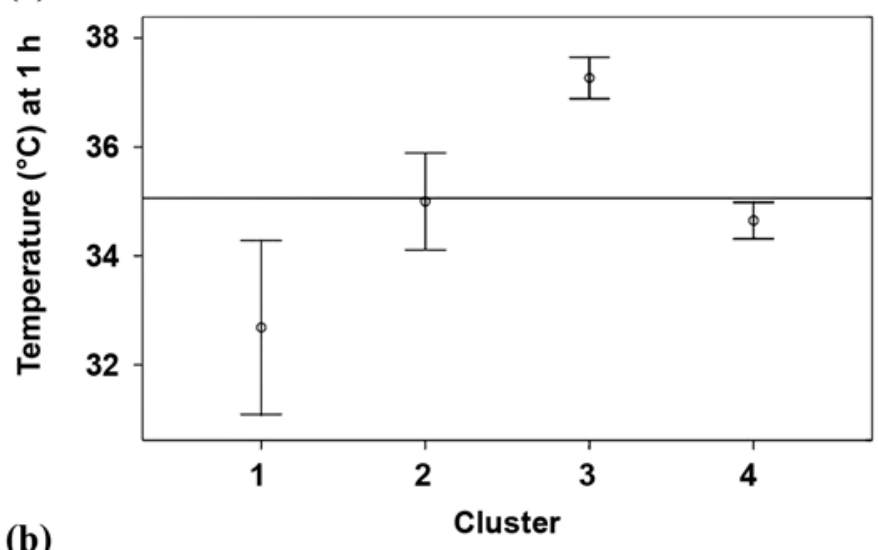

(b)

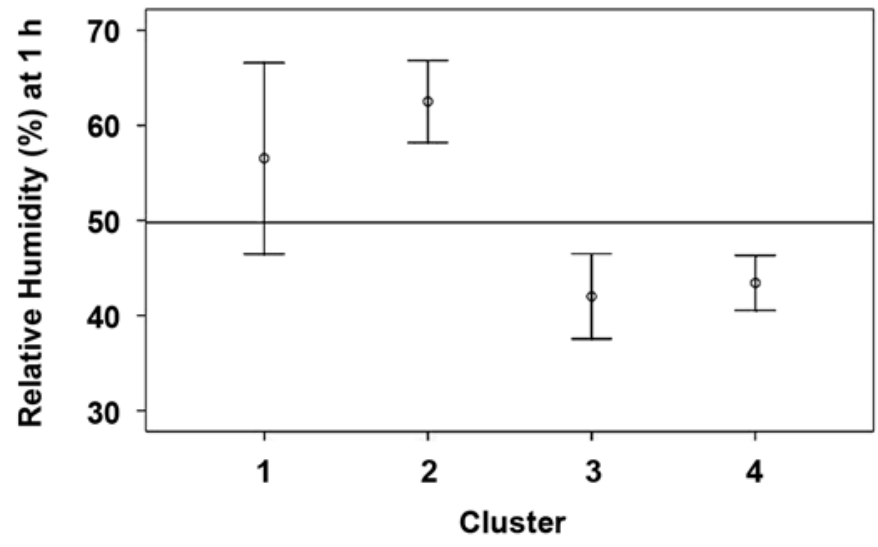

Figure 4.

Means and confidence intervals for temperature $\left({ }^{\circ} \mathrm{C}\right) 1 \mathrm{~h}$ after contact and relative humidity (\%) $1 \mathrm{~h}$ after contact when four clusters were generated. Enables upper and lower thresholds for these parameters to be defined.

below 40 percent were considered "high moisture dissipaters" and above 60 percent, "low moisture dissipaters.” These results yielded a classification table in which 14 (44\%) of the cushions tested were high moisture dissipaters and 13 (41\%) were high heat dissipaters. Seven (22\%) of the cushions were both low heat and low moisture dissipaters. Four cushions (12\%) were both high heat and high moisture dissipaters. Of these, two were gel and two were viscofoam. However, although these groupings can be created, statistical analysis only permits us to differentiate two distinct groups or clusters containing cushions with similar properties.

\section{DISCUSSION}

We report an apparatus and method for measuring the heat and moisture dissipation of wheelchair cushions under
Table 9.

Proposed classification system for cushion thermal properties.

\begin{tabular}{lccccc}
\hline \multirow{2}{*}{ Property } & \multicolumn{3}{c}{ Heat Dissipation } & & \multicolumn{2}{c}{ Moisture Dissipation } \\
\cline { 2 - 3 } & High & Low & & High & Low \\
\hline $\mathrm{T}_{1}<34{ }^{\circ} \mathrm{C}$ & $\mathrm{X}$ & - & & - & - \\
$\mathrm{T}_{1}>36.5{ }^{\circ} \mathrm{C}$ & - & $\mathrm{X}$ & & - & - \\
$\mathrm{H}_{1}<40 \% \mathrm{RH}$ & - & - & & $\mathrm{X}$ & - \\
$\mathrm{H}_{1}>60 \% \mathrm{RH}$ & - & - & & - & $\mathrm{X}$ \\
\hline $\mathrm{RH}=$ relative humidity, $\mathrm{T}_{1}=$ temperature $\left({ }^{\circ} \mathrm{C}\right) 1 \mathrm{~h}$ after contact, $\mathrm{H}_{1}=$ relative \\
humidity (\%) $1 \mathrm{~h}$ after contact.
\end{tabular}

simulated loading conditions with a rigid, buttock-shaped indenter (TRCLI). This system is not intended to measure the properties of the materials in absolute units such as watts per square meter per hour or water vapor measured in kilograms per square meter per hour, but instead the TRCLI is designed to create conditions similar to those produced by the human body when supported on typical wheelchair cushion materials. The heat and moisture output of the TRCLI has been designed to simulate the sensible and insensible output of the human body under testing conditions under standard laboratory conditions.

We used the data produced by a sample of 32 widely used wheelchair cushions to illustrate the range of values obtained for parameters defined from a $2 \mathrm{~h}$ testing session. These parameters gave indications of both the levels of interface temperature and humidity generated by this range of cushions and also their rates of change in the first and second hours of testing.

The test results demonstrate that an acceptable level of repeatability can be achieved with this system with a 95 percent confidence interval of $\pm 1^{\circ}$ (coefficient of variation [CV] of $4.4 \%$ ) for the interface temperature after $1 \mathrm{~h}$ and \pm 3 percent $\mathrm{RH}$ (CV 7.1\%) for the associated level of humidity.

Statistically significant differences in temperature after 1 and $2 \mathrm{~h}$ were recorded for the measurements taken at different anatomical sites on the TRCLI. The perineal area was warmest, followed by the IT region. The humidity level at these sites was not significantly different.

We classified the cushions in generic terms to represent the materials and method of construction. Analysis showed a strong correlation between the interface temperature at 1 and $2 \mathrm{~h}$ with properties of the core material. The results showed weak significant differences in moisture dissipation that correlated with the core material. Composite design did influence heat dissipation but not water vapor dissipation. Other cushion characteristics, such as whether the cushion was contoured or the type of cover 
used, were not found to significantly alter the thermal and humidity parameters. These results confirm that to inform clinicians, users, and providers, product-specific testing of thermal properties of wheelchair cushions is needed rather than such simple guidelines as "foam is a poor heat dissipater compared with gel.”

We used cluster analysis to determine whether the cushions could be classified into groups with distinctive properties (high/low heat/moisture dissipaters). The cushions' material properties were included in the cluster processing. As expected, the material properties did not strongly influence the cluster in which a cushion was placed, but the heat/moisture dissipation parameters effectively created two distinct groups (Clusters 1 and 2).

Cluster 1 cushions tend to dissipate heat more effectively but are less effective in dissipating moisture than Cluster 2 cushions. Cluster models were produced for the measurements taken at each of the anatomical sites on the TRCLI (thigh, IT, perineum) and were also lumped together to form a "combined site" data set. We analyzed whether the anatomical site used to create the cluster model modified the allocation of cushions to cluster and found that it made little difference. Combining the data from all the anatomical sites was adequate to assign these cushions to an appropriate classification cluster.

Intuitively, cushions might be expected to fall into one of four classes: high/low heat dissipaters and high/ low moisture dissipaters. When we permitted the clustering techniques used to automatically determine the number of clusters that can be created from the data, they defined two clusters. However, we chose to use the twostep method to force the allocation of cushions to one of four clusters, thereby allowing clinically relevant classes to be considered.

It would be interesting to undertake a future study that compared these objective measurements with the subjective assessments of users of cushions in these classes. The results from this TRCLI-based test closely parallel those seen in human studies on a limited cushion set [32]. Also conceivable is that an index, much like the comfort index used in meteorology, could be defined, combining the thermal dissipation and moisture dissipation characteristics into a single score. Environmental heat indices cannot be translated to body-cushion interface comfort, because environmental conditions affect the whole body and the ability to maintain homeostasis.

Finally, it is important to remember that these tests were performed in a controlled environment. Numerous factors are not easily reproduced in a standardized technical test method. For example, the influence of environmental temperature and metabolic factors substantially modify sweating rates and heat output by the body. Localized pressure suppresses sweat production [30] and so there is a complex interaction between the mechanical, environmental, and physiological conditions that affect the performance of the cushion.

\section{CONCLUSIONS}

We have demonstrated an effective method for measuring the heat and moisture dissipation characteristics under simulated loading conditions for seat cushions and provided detailed specifications for its construction. The method was found to be repeatable and successfully differentiated cushions into clusters according to their capacity to dissipate heat and moisture. Simple classification of cushion properties was not found to be an adequate predictor of thermal dissipation properties. For a sample of commercially available cushions, 22 percent were found to be low heat and moisture dissipaters and 12 percent were found to possess both attributes according to a proposed classification scheme based on this date from this study. Clearly, room for improvement exists in the design of cushion thermal dissipation performance, and the proposed TRCLI offers a tool for both designers and objective evaluators of existing and future products.

\section{ACKNOWLEDGMENTS}

\section{Author Contributions:}

Study concept and design: M. Ferguson-Pell, H. Hirose, G. Nicholson, E. Call.

Acquisition of data: M. Ferguson-Pell, G. Nicholson, E. Call. Analysis and interpretation of data: M. Ferguson-Pell, E. Call. Drafting of manuscript: M. Ferguson-Pell, E. Call.

Critical revision of manuscript for important intellectual content: M. Ferguson-Pell, H. Hirose, E. Call.

Statistical analysis: M. Ferguson-Pell, E. Call.

Obtained funding: M. Ferguson-Pell, H. Hirose, E. Call.

Administrative, technical, or material support: M. Ferguson-Pell, H. Hirose, G. Nicholson, E. Call.

Study supervision: M. Ferguson-Pell, G. Nicholson, E. Call.

Financial Disclosures: The authors have declared that no competing interests exist.

Funding/Support: This material was based on work supported in part by peer-reviewed grants from the Butterworth Foundation Japan Research Exchange, UK NHS CEP, Association for Spinal Research 
Rehabilitation and Education, Rehabilitation Engineering Research Society of North America, and the National Pressure Ulcer Advisory Panel (USA).

Additional Contributions: This study gained significantly from the contributions and suggestions made by those developing the 16840 family of standards for seating and seat cushions, the ISO TC 173/SC-1/ WG11 Working Group, chaired by Dr. Geoff Bardsley. It is with great sadness that we report that Dr. Graham Nicholson, one of the authors of this article, died tragically before its completion. He inspired this study, led the design of the TRCLI, and was responsible for collection of the data used to produce its outcomes. His wife Sarah has agreed to the content of the article, thereby enabling Dr. Nicholson's authorship of this work to be recognized.

\section{REFERENCES}

1. Vanderwee K, Clark M, Dealey C, Gunningberg L, Defloor T. Pressure ulcer prevalence in Europe: A pilot study. J Eval Clin Pract. 2007;13(2):227-35. [PMID: 17378869] DOI:10.1111/j.1365-2753.2006.00684.x

2. Reger SI, Ranganthan VK, Sahgal V. Support surface interface pressure, microenvironment, and prevalence of pressure ulcers: An analysis of the literature. Ostomy Wound Manage. 2007;53(10):50-58. [PMID: 17978415]

3. Schue RM, Langemo DK. Prevalence, incidence, and prediction of pressure ulcers on a rehabilitation unit. J Wound Ostomy Continence Nurs. 1999;26(3):121-29.

[PMID: 10711121] DOI:10.1016/S1071-5754(99)90029-3

4. Kokate JY, Leland Kj, Held AM, Hansen GL, Kveen GL, Johnson BA, Wilke MS, Sparrow EM, Iaizzo PA. Temperature-modulated pressure ulcers: A porcine model. Arch Phys Med Rehabil. 1995;76(7):666-73. [PMID: 7605187] DOI:10.1016/S0003-9993(95)80637-7

5. Wildnauer RH, Bothwell JW, Douglass AB. Stratum corneum biomechanical properties. I. Influence of relative humidity on normal and extracted human stratum corneum. J Invest Dermatol.1971;56(1):72-78. [PMID: 5556501] DOI:10.1111/1523-1747.ep12292018

6. Stewart SF, Palmieri V, Cochran GV. Wheelchair cushion effect on skin temperature, heat flux, and relative humidity. Arch Phys Med Rehabil. 1980;61(5):229-33. [PMID: 7377945]

7. Vander AJ, Sherman JH, Luciano DS. Human physiology: The mechanisms of body function. 4th Edition. Blacklick (OH): McGraw-Hill; 1985.

8. Arrhenius, S. [On the rate of reaction of the inversion of sucrose by acids]. Zeitschrift fuer physikalische Chemie. 1889;4:226-48. German.

9. Brown AC. Energy metabolism. In: Ruch TC, Patton HD, Howell WH, editors. Physiology and biophysics. Philadelphia (PA): Saunders; 1965.
10. Brengelmann G. Temperature regulation. In: Ruch TC, Patton HD, Howell WH, editors. Physiology and biophysics. Philadelphia (PA): Saunders; 1965.

11. Nicholson GP, Scales JT, Clark RP, De Calcina-Goff ML. A method for determining the heat transfer and water vapour permeability of patient support systems. Med Eng Phys. 1999;21(10):701-12. [PMID: 10717550] DOI:10.1016/S1350-4533(00)00003-5

12. Figliola RS. A proposed method for quantifying low-airloss mattress performance by moisture transport. Ostomy Wound Manage. 2003;49(1):32-42. [PMID: 12532032]

13. Siekman AR, Axelson PW, Noon JH, Folkedal AT, Wisnia RJ. Preliminary test methods for wheelchair seating components. Proceedings of the RESNA '98 Annual Conference; 1998 Jun 26-30; Minneapolis, MN. Arlington (VA): RESNA Press; 1998. p. 161-63.

14. Reddy NP, Patel H, Cochran GV, Brunski JB. Model experiments to study the stress distributions in a seated buttock. J Biomech. 1982;15(7):493-504. [PMID: 7130205] DOI:10.1016/0021-9290(82)90003-3

15. Bain DS, Scales JT, Nicholson GP. A new method of assessing the mechanical properties of patient support systems (PSS) using a phantom. A preliminary communication. Med Eng Phys. 1999;21(5):293-301.

[PMID: 10576420]

DOI:10.1016/S1350-4533(99)00053-3

16. International Organization for Standardization. Wheelchair seating-Part 2: Determination of physical and mechanical characteristics of devices intended to manage tissue integrity-Seat cushions. Geneva (Switzerland): International Organization for Standardization; 2007. Report No.: ISO 16840-2.

17. Staarink HA. Sitting posture, comfort and pressure: Assessing the quality of wheelchair cushions. Delft (the Netherlands): Delft University Press; 1995.

18. International Organization for Standardization. TextilesPhysiological effects-Measurement of thermal and watervapour resistance under steady-state conditions (sweating guarded-hotplate test). Geneva (Switzerland): International Organization for Standardization; 1993. Report No.: ISO 11092.

19. ASTM Standard E96/E96M-05 Standard test methods for water vapor transmission of materials. West Conshohocken (PA): ASTM International; 2005.

20. Faust E, Lothar K, Pfahler K, Witzmann M, inventors; DaimlerChrysler AG, assignee. Method and system for quantitative determination of seat climate on seat cushions. United States patent 6,116,778. 2000 Sep 12.

21. Reger SI, Adams TC, Maklebust JA, Sahgal V. Validation test for climate control on air-loss supports. Arch Phys Med Rehabil. 2001;82(5):597-603. [PMID: 11346834] DOI:10.1053/apmr.2001.20837 
22. ASTM Standard C 177 Standard test method for steadystate heat flux measurements and thermal transmission properties by means of a guarded-hot-plate apparatus. West Conshohocken (PA): ASTM International; 2002.

23. McCullough EA, Huang J, Kim CS. An explanation and comparison of sweating hot plate standards. J ASTM Int. 2004;1(7):Paper ID JAI12098.

24. Diesing P. Prüf- und Bewertungsmethoden für Antidekubitus-Systeme [dissertation]. [Berlin]: Technische Universität Berlin; 2006.

25. ASTM D1518-85(1998)e1 Standard test method for thermal transmittance of textile materials. West Conshohocken (PA): ASTM International; 1998.

26. ASTM F1868-98 Standard test method for thermal and evaporative resistance of clothing materials using a sweating hot plate. West Conshohocken (PA): ASTM International; 1998.
27. ASTM F2370-05 Standard test method for measuring the evaporative resistance of clothing using a sweating manikin. West Conshohocken (PA): ASTM International; 2005.

28. ASTM F 1291-04 Standard test method for measuring the thermal insulation of clothing using a heated manikin. West Conshohocken (PA): ASTM International; 2004.

29. International Commission on Radiological Protection. Report of the task group on reference man. Oxford (UK): Pergamon Press; 1975. (ICRP Publications Series No. 23).

30. Kuno Y. Human perspiration. Springfield (IL): Thomas; 1956.

31. Lide DR. CRC handbook of chemistry and physics. 84th Edition. Danvers (MA): CRC Press; 2003.

32. Call E, Levy B, Jones R, Oberg B. Classical thermodynamics of wheelchair cushions and temperature intervention. Nineteenth International Seating Symposium; 2003 Feb 27-Mar 1; Orlando, FL.

Submitted for publication October 16, 2008. Accepted in revised form April 7, 2009. 